có kết quả chụp $X$ quang, nếu có thêm MRI sẽ rất hữu ích, đặc biệt là đối vớ thoái hóa khớp gối mức độ vừa phải trước khi phẫu thuật nội soi khớp. Hơn nữa, nếu MRI đã được thực hiện, có thể không cần thiết chụp $X$ quang trong các trường hợp thoái hóa khớp gối mức độ nhẹ.

\section{TÀI LIÊU THAM KHẢO}

1. Vallotton JA, Meuli RA, Leyvraz PF, Landry M. Comparison between magnetic resonance imaging and arthroscopy in the diagnosis of patellar cartilage lesions: a prospective study. Knee Surg Sports Traumatol Arthrosc. 1995;3:157-162.

2. Von Engelhardt LV, Lahner M, Klussmann A, et al. Arthroscopy vs. MRI for a detailed assessment of cartilage disease in osteoarthritis: diagnostic value of MRI in clinical practice. BMC Musculoskelet Disord. 2010;11:75.
3. Quatman CE, Hettrich CM, Schmitt LC, Spindler KP. e clinical utility and diagnostic performance of magnetic resonance imaging for identi cation of early and advanced knee osteoarthritis: a systematic review. Am J Sports Med. 2011;39:1557-1568.

4. Kijowski $R$, Blankenbaker DG, Davis KW, Shinki K, Kaplan LD, De Smet AA. Comparison of 1.5- and 3.0-T MR imaging for evaluating the articular cartilage of the knee joint. Radiology. 2009;250:839-848.

5. Agnesi F, Amrami KK, Frigo CA, Kaufman KR. Comparison of cartilage thick- ness with radiologic grade of knee osteoarthritis. Skeletal Radiol. 2008;37:639-643.

6. Galea A, Giu re B, Dimmick S, Coolican M, Parker D. e accuracy of mag- netic resonance imaging scanning and its in uence on management decisions in knee surgery. Arthroscopy. 2009;25:473-480.

\title{
KẾT QUẢ CHĂM SÓC NGƯờI BÊ̂NH SAU PHẪU THUÂT UNG THƯ DẠ DÀY TẠI BÊ̂NH VIÊ̂N K NĂM 2020 - 2021 VÀ MộT Số YẾU Tố LIÊN QUAN
}

\section{TÓM TẮT}

Phương pháp chủ yếu trong điều trị ung thư da dày là phâuu thuật bao gồm những trường hợp bệnh giai đoạn sớm hay cả giai đoạn muộn. Sự theo dõi chăm sóc người bệnh của cán bộ điều dưỡng đóng vai trò rất quan trọng giúp cho người bệnh sau phẫu thuật ung thư da dày đat kết quả tốt trong điều tri. Mục tiêu: Mô tả đặc điểm lâm sàng, phân tích kểt quả chăm sóc người bênh sau phẩu thuật ung thư dạ dày và tìm hiểu một số yếu tố liên quan. Đối tượng và phương pháp: Thiết kế nghiên cứu mô tả cắt ngang trên 148 người bệnh ung thư dạ dày sau phẫu thuât cắt đoan da dày, thu thâp thông tin về chăm sóc ngừ̛̛̛i bệnh theo quy trình điều dưỡng tại phòng hậu phẫu và các phòng bênh cho đến khi người bênh ra viện. Kết quả: Kểt quả chăm sóc người bệnh tốt là $83,4 \%$. Các yếu tố liên quan đến kết quả chắm sóc tốt gồm: Nhóm tuổi, thói quan cá nhân, bệnh lý kèm theo, giai đoạn bệnh, phương pháp phẩu thuật và thời điểm ăn đường miệng.

Từ khóa: Ung thư dạ dày, phẫu thuật, chăm sóc.

\section{SUMMARY \\ RESULTS OF CARE OF PATIENTS AFTER SURGERY STOMACH CANCER AT K HOSPITAL IN 2020 - 2021 AND SOME FACTORS RELATED}

*Bệnh viên $K$

Chịu trách nhiệm chính: Trân Đắc Thành

Email: thanhbvk@gmail.com

Ngày nhân bài: 10.9.2021

Ngày phản biên khoa hoc: 28.10.2021

Ngày duyệt bài: 12.11.2021

\section{Trần Đắc Thành*}

The main method in the treatment of stomach cancer is surgery, including cases of early or late stage disease. The follow-up care of patients by nursing staff plays a very important role in helping patients after gastric cancer surgery achieve good results in treatment. Objectives: Description of the clinical features, analyze the outcome of patient care after gastric cancer surgery and find out some related factors. Subjects and methods: Design a crosssectional descriptive study on 148 gastric cancer patients after gastric bypass surgery, collect information on patient care according to the nursing process in the postoperative room and other medical staff. patient care until the patient is discharged from the hospital. Results: Good patient care outcome was $83.4 \%$. Factors related to good care outcomes include: Age group, personal habits, comorbidities, disease stage, surgical method and time of oral intake.

Keywword: Stomach cancer, surgery, take care

\section{I. ĐẶT VẤN ĐỀ}

Theo thống kê của Cớ quan nghiên cứu ung thư quốc tế (IARC), năm 2020 ung thư dạ dày có tỷ lệ mắc phổ biến thứ năm trên toàn thể giới với $5,6 \%$ tương đương với 1,089 triệu người mắc mới, tỷ lệ tử vong đứng thứ tư ở cả hai giới. Cũng theo báo cáo trên thì tại Việt Nam năm 2020 ước tính có 17.906 ca mắc mới đứng thứ tư và chiếm 9,8\% trong các loại ung thư [1].

Phẫu thuật là phương pháp chủ yếu điều trị ung thư dạ dày. Ớ giai đoạn sớm, ung thư còn giới hạn tại chỗ và vùng, phẫu thuật được lựa chọn là phương pháp điêuu trị triệt căn. Những 
trường hợp bệnh ở giai đoạn muộn, phẫu thuật vẫn là phương pháp điều trị cơ bản. Các biện pháp hoá trị và xạ trị đóng vai trò bổ trợ hoặc điều trị triệu chứng.

Để có kết quả điều trị tốt cho những bệnh nhân phẫu thuật ung thư dạ dày thì ngoài sự phụ thuộc vào tình trạng bệnh của chính bệnh nhẩn, vai trò điều trị của bác sĩ thì sự theo dõi chăm sóc của cán bộ điều dưỡng cũng rất quan trọng. Điều dưỡng chăm sóc là người đã đồng hành cùng bác sĩ trong việc điều trị và theo dõi chăm sóc người bệnh từ khi vào viện cho đến khi ra viện. Hơn nữa, điều dưỡng mới chính là người bên cạnh người bệnh 24/24 giờ, hướng dẫn người bệnh, người nhà người bệnh chăm sóc vết mổ, chăm sóc dinh dương sau mổ và thực hiện chăm sóc cho người bệnh như chăm sóc tâm lý, ăn uống, theo dõi những bất thường, thực hiện kịp thời các y lệnh của bác sỹ góp phần hạn chế những biến chứng sau phẫu thuật, đáp ứng các nhu câu cơ bản của người bệnh, đạt được sự hài lòng cao khi họ nằm viện. Tuy nhiên, đến nay chưa có một nghiên cứu nào tại Bệnh viện $K$ thực hiện nghiên cứu về công tác hướng dẫn, chằm sóc người bệnh sau phẫu thuật ung thư dạ dày, đó là lý do chúng tôi tiến hành nghiên cứu đề tài với mục tiêu "Phân tích kết quả chăm sóc người bệnh sau phẫu thuật ung thư dạ dày và tìm hiểu một số yếu tố liên quan".

\section{II. ĐỐI TƯợNG VÀ PHƯƠNG PHÁP NGHIÊN CỨU \\ 1. Thời gian và địa điểm}

- Thời gian nghiên cứu: từ tháng 10/2020 đến tháng 08/2021.

- Địa điểm nghiên cứu: các khoa ngoại của Bệnh viện $K$ cớ sở Tân Triều.

\section{2. Đối tượng nghiên cứu}

> Tiêu chuân lựa chọn

- Người bệnh được chẩn đoán ung thư dạ dày.

- Được phẫu thuật cắt đoạn dạ dày.

\section{> Tiêu chuẩn loai trừ}

- Người bệnh phẫu thuật cắt toàn bộ dạ dày, thăm dò, nối vị tràng.

- Người bênh trên 80 tuổi.

- Người bệnh mắc 2 loại ung thư.

3. Thiết kế nghiên cứu: Nghiên cứu mô tả cắt ngang.

4. Chọn mẫu và cỡ mẫu. Nghiên cứu sử dụng phương pháp chọn mẫu thuận tiện, lựa chọn tất cả người bệnh đủ tiêu chuẩn trong thời gian nghiên cứu. Kết quả có 175 người bệnh đủ tiêu chuẩn lựa chọn vào nghiên cứu.

\section{Công cụ và kỹ thuật thu thập số liệu}

> Công cụ nghiên cứu
- Sử dụng bệnh án nghiên cứu được xây dựng dựa trên các biến số và chỉ số phù hợp với mục tiêu.

- Bệnh án nghiên cứu gồm: thông tin chung của người bệnh, đặc điểm của phẫu thuật, triệu chứng lâm sàng sau phẫu thuật, kết quả chăm sóc người bệnh tại 5 thời điểm: thời gian nằm hậu phẫu (hồi sức tích cực), sau 24 giờ phẫu thuật, ngày thứ 3 , ngày thứ 5 và ngày thứ 7 sau phẫu thuật.

- Sử dụng các tiêu chí đánh giá biến chứng phẫu thuật theo các hướng dẫn lâm sàng gồm các biến chứng: viêm phổi mắc phải, nhiễm khuẩn vết mổ, chảy máu, rò/bục miệng nối.

- Quy ước cách đánh giá một sổ chỉ số bằng cách sử dụng bảng kiểm quan sát:

+ Đánh giá vận động:

Thời điểm nằm hậu phẫu: Tốt là người bệnh có thể thực hiện được các động tác theo yêu câu bình thường; Khá là người bệnh có thể làm được một phần động tác theo yêu cầu một cách chậm chạp và khó khăn; Kém là người bệnh không thể vận động theo yêu câu.

Thời điểm 24 giờ, 3 ngày, 5 ngày, 7 ngày: Tốt là người bệnh tự ngồi dậy, đi lại được; Khá là người bệnh chỉ vận động tại giường, ngồi dậy có người trợ giúp và không đi lại quanh giường được; Kém là người bệnh không ngồi dậy được, khồng đi lại được, chỉ nằm tại giường.

+ Đánh giá một số hướng dẫn của điều dưỡng cho người bệnh: Tốt là thực hiện đúng và đủ các quy trình hướng dẫn đạt ước lượng khoảng $90 \%$; Sơ sài là thực hiện quy trình đạt ước lượng dưới $90 \%$.

$>$ Kỹ thuật thu thập số liệu

- Các thông tin thu thập từ hồ sơ bệnh án kết hợp quan sát, theo dõi bệnh nhân và đánh giá theo bảng kiểm, từ đó tổng hợp dữ liệu vào bệnh án nghiên cứu.

6. Xử lý và phân tích số liệu. Số liệu thu thập được nhập vào excel, xử lý và phân tích số liệu bằng phần mềm SPSS 22.0

Sử dung test thống kê là Chi bình phương $\left(x^{2}\right)$ và Fisher's exact test để kiểm định sự khác biệt.

Để đánh giá kết quả chăm sóc người bệnh tốt/khá/kém khi phân tích số liệu, tác giả đã lượng hóa các dữ liệu bằng cách xây dựng bảng tính điểm dựa trên 5 chỉ số về chăm sóc người bệnh sau gồm:

+ Tổng số ngày điều trị: 30 điểm.

+ Biến chứng sau phấu thuâat: 20 điểm.

+ Tình trạng vết mổ: 15 điểm.

+ Người bệnh và người nhà tuân thủ điều trị: 
15 điểm.

+ Vận động của người bệnh: 20 điểm.

Phân loại kết quả chăm sóc người bệnh gồm:

- Kết quả tốt: 80 - 100 tổng điểm

- Kết quả khá: 70 - 79 điểm

- Kết quả kém: < 70 điểm

7. Đạo đức nghiên cứu. Các thông tin thu thập chỉ phục vụ cho mục đích nghiên cứu nhằm nâng cao chất lượng điều trị và chăm sóc cho người bệnh.

\section{KẾT QUẢ NGHIÊN CỨU}

Bảng 1: Đặc điểm chung của đôî tượng nghiên cứu ( $N=175)$

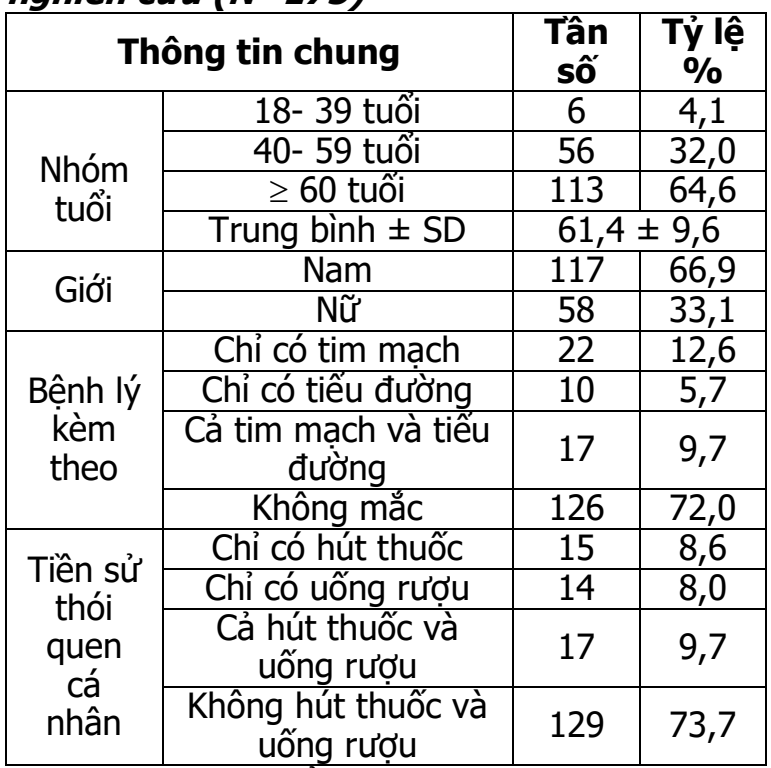

Nhận xét: Tuối trung bình của đối tượng nghiên cứu là 61,45 tương ứng với nhóm $\geq 60$ tuổi chiếm tỷ lệ cao nhất là $64,6 \% ; 2 / 3$ người bệnh là nam giới. Phần lớn người bệnh không có bệnh lý tim mạch hoặc tiểu đường kèm theo. Có $26,3 \%$ người bệnh có thói quen hút thuốc hoặc/và uống rượu trước đó.

Bảng 2: Đặc điểm phẫu thuật và lâm sàng người bệnh sau phấu thuật ( $N=175)$

\begin{tabular}{|c|c|c|c|}
\hline \multicolumn{2}{|c|}{ Thông tin chung } & $\begin{array}{c}\text { Tân } \\
\text { số }\end{array}$ & $\begin{array}{c}\text { Tỳ lệ } \\
\%\end{array}$ \\
\hline \multirow{3}{*}{$\begin{array}{c}\text { Giai đoạn } \\
\text { bệnh }\end{array}$} & Giai đoạn I & 43 & 24,6 \\
\cline { 2 - 4 } & Giai đoạn II & 82 & 46,9 \\
\cline { 2 - 4 } & Giai đoạn III & 50 & 28,6 \\
\cline { 2 - 4 } & Giai đoạn IV & 0 & 0,0 \\
\hline $\begin{array}{c}\text { Phương pháp } \\
\text { phẫu thuật }\end{array}$ & Mố mơ & 132 & 75,4 \\
\hline \multirow{2}{*}{$\begin{array}{c}\text { Thời gian } \\
\text { phẫu thuật }\end{array}$} & $<120$ phút & 43 & 24,6 \\
\cline { 2 - 4 } & $120-160$ phút & 151 & 2,3 \\
\cline { 2 - 4 } & $>160$ phút & 20 & 11,4 \\
\hline Mức độ đau & Dau ít & 133 & 76,0 \\
\hline
\end{tabular}

\begin{tabular}{|c|c|c|c|}
\hline \multirow[t]{2}{*}{ sau mố } & Đau vừa & 42 & 24,0 \\
\hline & Đau nhiều & 0 & 0,0 \\
\hline \multirow{2}{*}{$\begin{array}{l}\text { Dẫn lưu } \\
\text { ổ bụng }\end{array}$} & Bình thường & 168 & 96,0 \\
\hline & Không bình thường & 7 & 4,0 \\
\hline \multirow{2}{*}{$\begin{array}{l}\text { Dâ̂n lưu } \\
\text { thông tiểu }\end{array}$} & Bình thường & 173 & 98,9 \\
\hline & Không bình thường & 2 & 1,1 \\
\hline \multirow{2}{*}{$\begin{array}{l}\text { Dịch thông } \\
\text { dạ dày }\end{array}$} & Bình thường & 161 & 92,0 \\
\hline & Không bình thường & 14 & 8,0 \\
\hline \multirow{3}{*}{$\begin{array}{l}\text { Thời gian } \\
\text { trung tiện }\end{array}$} & < 2 ngày & 4 & 2,3 \\
\hline & 2 -3 ngày & 148 & 84,6 \\
\hline & $>3$ ngày & 23 & 13,1 \\
\hline \multirow{4}{*}{$\begin{array}{c}\text { Thời điểm ăn } \\
\text { đường miệng } \\
\text { Nôn, buồn } \\
\text { nôn }\end{array}$} & Sau 2 -3 ngày PT & 68 & 38,9 \\
\hline & Sau trung tiện & 107 & 61,1 \\
\hline & Có & 31 & 17,7 \\
\hline & Không & 144 & 82,3 \\
\hline \multirow{2}{*}{$\begin{array}{c}\text { Chướng bựng } \\
\text { đầy hơi }\end{array}$} & Có & 19 & 10,9 \\
\hline & Không & 156 & 89,1 \\
\hline
\end{tabular}

Nhân xét: Đặc điểm phẫu thuật: Người bênh ở giai đoạn II chiếm gần một nửa, không có người bệnh giai đoạn IV. Phương pháp phẫu thuật phần lớn là mổ mở. Thời gian phẫu thuật chủ yếu trong khoảng từ $120-160$ phút.

Đắc điểm lâm sàng người bệnh: Phần lớn người bệnh đau ít chiếm $76,0 \%$ và không có người bềnh nào đau nhiều. Tình trạng dẫn lưu ổ bụng, dấn lưu thông tiểu và dịch thông dạ dày hẩu hết là bình thường. Thời gian trung tiện nhiều nhất là sau 2-3 ngày, đây cũng là thời điểm có hơn một nửa người bệnh ăn đường miênng. Có khoảng $17,7 \%$ người bệnh có nôn, buồn nôn và $10,9 \%$ có chướng bụng đầy hơi.

Bảng 3: Kêt quả chăm sóc người bênh ung thư dạ dày sau phẫu thuật ( $N=175)$

\begin{tabular}{|c|c|c|c|}
\hline \multicolumn{2}{|c|}{ Thông tin chung } & \multirow{2}{*}{$\begin{array}{c}\text { Tân } \\
\text { số }\end{array}$} & \multirow{2}{*}{$\begin{array}{c}\begin{array}{c}\text { Tỷ lệ } \\
\text { \% }\end{array} \\
83,4\end{array}$} \\
\hline \multirow{3}{*}{$\begin{array}{l}\text { Kết quả chăm } \\
\text { sóc người bệnh } \\
\text { nói chung }\end{array}$} & Tốt & & \\
\hline & Khá & 16 & 9,2 \\
\hline & Kém & 13 & 7,4 \\
\hline \multirow{3}{*}{$\begin{array}{c}\text { Tổng số ngày } \\
\text { điêuu trị }\end{array}$} & $<8$ ngày & 66 & 37,7 \\
\hline & $8-10$ ngày & 89 & 50,9 \\
\hline & $>10$ ngày & 20 & 11,4 \\
\hline \multirow{3}{*}{$\begin{array}{c}\text { Tình trạng vết } \\
\text { mổ }\end{array}$} & Tốt & 97 & 55,4 \\
\hline & Trung bình & 78 & 44,6 \\
\hline & Kém & 0 & 0,0 \\
\hline \multirow{2}{*}{$\begin{array}{l}\text { Người bệnh và } \\
\text { người nhà tuân } \\
\text { thủ điều trị }\end{array}$} & Tốt & 138 & 78,9 \\
\hline & Chưa tốt & 37 & 21,1 \\
\hline \multirow{5}{*}{$\begin{array}{l}\text { Biến chứng sau } \\
\text { phẫu thuật }\end{array}$} & Chảy máu & 4 & 2,3 \\
\hline & Viêm phổi & 4 & 2,3 \\
\hline & $\begin{array}{c}\text { Nhiềm khuấn vết } \\
\text { mổ }\end{array}$ & 3 & 1,7 \\
\hline & $\begin{array}{c}\text { Rò, bục miệng } \\
\text { nối }\end{array}$ & 1 & 0,6 \\
\hline & Không biến & 164 & 93,7 \\
\hline
\end{tabular}




\begin{tabular}{|c|c|c|c|}
\hline & chứng & & \\
\hline \multirow{2}{*}{$\begin{array}{c}\text { Vận động sau } \\
\text { phẫu thuật }\end{array}$} & Tốt & 171 & 97,7 \\
\cline { 2 - 4 } & Khá & 4 & 2,3 \\
\cline { 2 - 4 } & Kém & 0 & 0,0 \\
\hline \multirow{3}{*}{$\begin{array}{c}\text { Thời điểm ăn } \\
\text { đường miệng }\end{array}$} & Ngày 1 & 0 & 0,0 \\
\cline { 2 - 4 } & Ngày 3 & 67 & 38,3 \\
\cline { 2 - 4 } & Ngày 5 & 93 & 53,1 \\
\hline $\begin{array}{c}\text { Thực hiên tư } \\
\text { vấn tâm ìy cho cho } \\
\text { người bệnh }\end{array}$ & Tốt & 15 & 8,6 \\
\cline { 2 - 4 } & Chưa tốt & 3 & 172 \\
\hline
\end{tabular}

Nhận xét: Nhìn chung kết quả chăm sóc người bệnh là tốt chiếm tới $83,4 \%$, vẫn còn $7,4 \%$ người bệnh có kết quả chăm sóc kém. Tổng số ngày điều trị từ 8-10 ngày chiếm tỷ lệ cao nhất là 50,9\%. Hơn một nửa là tình trạng vết mổ tốt, còn lại là trung bình không có tình trạng kém. Có 1 người bệnh gặp 2 loại biến chứng sau phẫu thuật và 10 người gặp ít nhất 1 biến chứng chiếm tổng $6,3 \%$. Hầu hết người bệnh vận động tốt và cũng được điều dưỡng thực hiện tốt tư vấn tâm lý.

Bảng 4: Yêu tố liên quan tới kêt quả chăm sóc người bệnh ung thư dạ dày sau phẫu thuật

\begin{tabular}{|c|c|c|c|c|}
\hline \multirow{2}{*}{\multicolumn{2}{|c|}{ Đặc điểm đôii tượng nghiên cứu }} & \multicolumn{3}{|c|}{ Kiếm định sự khác biệt } \\
\hline & & \multirow{2}{*}{$\begin{array}{c}\text { KQ chăm sóc } \\
\text { tốt n (\%) } \\
6(100)\end{array}$} & \multirow{2}{*}{$\begin{array}{c}\begin{array}{c}\text { KQ chăm sóc } \\
\text { chưa tốt n (\%) }\end{array} \\
0\end{array}$} & P) \\
\hline \multirow{3}{*}{ Nhóm tuổi } & 18- 39 tuối & & & \multirow{3}{*}{0,026} \\
\hline & 40- 59 tuối & $52(92,9)$ & $4(7,1)$ & \\
\hline & $\geq 60$ tuối & $88(77,9)$ & $25(22,1)$ & \\
\hline \multirow{2}{*}{ Giới tính } & Nam & $95(81,2)$ & $22(18,8)$ & \multirow{2}{*}{0,259} \\
\hline & Nữ & $51(87,9)$ & $7(12,1)$ & \\
\hline \multirow{2}{*}{ Thói quen cá nhân } & $\begin{array}{l}\text { Hút thuốc và/ hoắc } \\
\text { uống rượu }\end{array}$ & $33(71,7)$ & $13(28,3)$ & 0,013 \\
\hline & Không & $113(87,6)$ & $16(12,4)$ & \\
\hline \multirow{2}{*}{ Bệnh lý kèm theo } & Có bệnh & $34(69,4)$ & $15(30,6)$ & \multirow{2}{*}{0,002} \\
\hline & Không bệnh & $112(88,9)$ & $14(11,1)$ & \\
\hline \multirow{2}{*}{ Giai đoạn bệnh } & Giai đoạn I, II & $114(91,2)$ & $11(8,8)$ & \multirow{2}{*}{$<0,001$} \\
\hline & Giai đoạn III & $32(64,0)$ & $18(36,0)$ & \\
\hline \multirow{2}{*}{ Phương pháp PT * } & Mố mở & $105(78,9)$ & $28(21,1)$ & \multirow{2}{*}{0,005} \\
\hline & Mố nội soi & $41(97,6)$ & $1(2,4)$ & \\
\hline \multirow{2}{*}{ Thời điểm ăn đường miệng } & $\leq 3$ ngày & $63(94,0)$ & $4(6,0)$ & \multirow{2}{*}{0,003} \\
\hline & $>3$ ngày & $83(76,9)$ & $25(23,1)$ & \\
\hline \multirow{2}{*}{ Vận động của người bệnh * } & Tốt & $144(84,2)$ & $27(15,8)$ & \multirow[t]{2}{*}{0,129} \\
\hline & Khá & $2(50,0)$ & $2(50,0)$ & \\
\hline \multirow{2}{*}{$\begin{array}{c}\text { Thực hiện tư vấn } \\
\text { tâm lý cho người bệnh * }\end{array}$} & Tốt & $145(84,3)$ & $27(15,7)$ & \multirow{2}{*}{0,072} \\
\hline & Chưa tốt & $1(33,3)$ & $2(66,7)$ & \\
\hline \multirow{2}{*}{$\begin{array}{l}\text { Điều dưỡng chăm sóc } \\
\text { tuân thủ rửa tay } *\end{array}$} & Tốt & $145(83,3)$ & $29(16,7)$ & \multirow{2}{*}{1,0} \\
\hline & Chưa tốt & $1(100)$ & 0 & \\
\hline \multirow{2}{*}{$\begin{array}{l}\text { Điều dưỡng tư vấn hướng dấn NB } \\
\text { và NN chăm sóc vệ sinh thân thể }\end{array}$} & Tốt & $144(83,2)$ & $29(16,8)$ & \multirow[b]{2}{*}{1,0} \\
\hline & Chưa tốt & $2(100)$ & 0 & \\
\hline
\end{tabular}

Kễt quả chăm sóc chưa tốt = kết quả chăm sóc khá + kết quả chăm sóc kém; *Fisher's exact test

Nhận xét: Sử dụng các test thống kê kiểm định sự khác biệt giữa nhóm người bệnh có kết quả chăm sóc tốt và nhóm người bệnh có kết quả chăm sóc chưa tốt với một số biến độc lập về tình trạng và hoạt động chăm sóc người bệnh cho thây một số yếu tổ có liên quan tới kết quả chăm sóc tốt mà sự khác biệt có ý nghĩa thống kê gồm: Nhóm tuổi, thói quan cá nhân, bệnh lý kèm theo, giai đoạn bệnh, phương pháp phẫu thuật và thời điểm ằn đường miệng.

\section{BÀN LUẬN}

* Thông tin chung của đối tượng nghiên cứu. Tuổi trung bình của đối tượng

nghiên cứu là 61,4 tương ứng với nhóm $\geq 60$ tuổi chiếm tỷ lệ cao nhất là $62,2 \%, 2 / 3$ người bệnh là nam giới. Kết quả này phù hợp với các báo cáo về tình hình mắc ung thư dạ dày trên thế giới, tỷ lệ mắc ung thư dạ dày liên quan nhiều đến tuối tác, tuổi càng cao tỷ lệ càng tăng và tỷ lệ tăng cao hơn bắt đầu từ 60 tuổi, tỷ lệ mắc chuẩn theo tuổi của ung thư dạ dày ở nam giới gấp đôi nữ giới [2], [1].

Giai đoạn bệnh nhiều nhất là giai đoạn II, không có bệnh nhân giai đoạn IV, đây là một tín hiệu vui cho thấy hiện nay nhiều bệnh nhân đã được phát hiện bệnh ở giai đoạn sớm hơn. 
Phương pháp phẫu thuật phần lớn là mổ mở, do vậy thời gian phẫu thuật chủ yếu trong khoảng từ $120-160$ phút.

Phần lớn người bệnh đau ít chiếm $76,0 \%$ và không có người bênh nào đau nhiều. Tình trạng dẫn lưu ổ bung, dẩn lưu thông tiểu và dịch thông dạ dày hầu hết là bình thường.

* Kết quả chăm sóc người bệnh. Chăm sóc bệnh nhân sau mổ là một công việc quan trọng nhằm phát hiện kịp thời các rối loạn sau mổ, chủ động ngăn ngừa và xử lý tai biến, biến chứng, qua đó góp phần không nhỏ đảm bảo cho thành công của phẫu thuật. Thực tế các hướng dẫn chăm sóc người bệnh hiện nay chưa đưa ra một quy định và tiêu chuẩn cụ thể nào về việc đánh giá kết quả chăm sóc người bệnh của điều dưỡng lâm sàng. Trong điều trị bằng phẫu thuật cho bất kỳ bệnh nhân nào thì mục đích cuối cùng là bệnh nhân được ra viện càng sớm càng tốt. Bệnh nhân chỉ được xuất viện khi tình trạng ổn định theo các tiêu chuẩn đánh giá về lâm sàng như không có biến chứng, tình trạng vết mổ tốt, vận động tốt. Tình trạng của bệnh nhân phần nào nói lên được sự chăm sóc của các điêu dưỡng. Để lượng hóa kết quả chăm sóc người bệnh, trong nghiên cứu này chúng tôi xây dựng cách tính điểm dựa trên 5 chỉ số có khả nằng ảnh hưởng cao đến kết quả chăm sóc người bệnh gồm: tổng số ngày điều trị, biến chứng sau phẫu thuật, tình trạng vết mổ, vận động và sự tuân thủ điêu trị của người bệnh và người nhà. Nhìn chung kết quả chăm sóc người bệ̂nh trong nghiên cứu là tốt chiếm tới $83,4 \%$, vẩn còn $7,4 \%$ người bệnh có kêt quả chăm sóc kém và $9,2 \%$ người bệnh có kết quả chăm sóc khá. Theo cách phân loại và tính điểm trong nghiên cứu này thì chỉ cần người bệnh có tổng số ngày điều trị trên 10 ngày hoặc có 2 biến chứng sau phẫu thuật thì đã được đánh giá là kết quả chăm sóc chưa tốt (khá hoặc kém), các chỉ số đánh giá đều có liên quan, ảnh hưởng lẫn nhau.

* Các yếu tố liên quan đến kết quả chăm sóc tốt và chưa tốt. Ung thư dạ dày là một bệnh ác tính và có tỷ lệ tử vong tương đối cao, hiện phương pháp chủ yếu điều trị một cách triệt để là phẫu thuật cắt dạ dày. Tuy nhiên, việc cắt dạ dày và các mô xung quanh cũng như bóc tách hạch bạch huyết là một chấn thương lớn cho bệnh nhân, có nguy cơ cao xảy ra các biến chứng, từ đó sẽ ảnh hưởng đến sự phục hồi của bệnh nhân sau phẫu thuật [3]. Nhiều nghiên cứu đã chỉ ra tâm quan trọng trong việc chăm sóc người bệnh sau phẫu thuật, trong đó vai trò của điều dưỡng là rất lớn [4]. Một nghiên cứu can thiệp năm 2019 của Trung Quốc đã đưa ra kết luận rằng sự can thiệp chăm sóc một cách đầy đủ, có hệ thống của điều dưỡng ở bệnh nhân ung thư da dày có thể rút ngắn thời gian hồi phục sau khi cắt da dày triệt để, giảm đáng kể tỷ lệ biến chứng [5]. Tuy nhiển, để có một kết quả phục hồi tốt cho người bệnh ngoài việc cần sự chăm sóc của điều dưỡng thì các yếu tố cá nhân như tuổi, thể trạng, giai đoạn bệnh, tiền sử cá nhân cũng có ảnh hưởng rất lớn.

Nghiên cứu sử dụng các test thống kê kiểm định sự khác biệt giữa nhóm người bệnh có kết quả chăm sóc tốt và nhóm người bệnh có kết quả chăm sóc chưa tốt với một số biến độc lập về tình trạng cá nhân người bệnh và các hoạt động chăm sóc của điều dưỡng cho thây những yểu tố liên quan đến kết quả chăm sóc chưa tốt hầu hết là các yếu tố về đặc điểm cá nhân là nhóm tuổi, tiền sử hút thuốc/uống rượu, tiền sử bệnh lý kèm theo, giai đoạn bệnh. Nhóm tuổi 1839 có kết quả chăm sóc cao hơn có ý nghĩa thống kê so với nhóm tuổi khác, điều này có thể do những bệnh nhân trẻ tuổi thì thường khỏe mạnh hơn, khả năng hồi phục nhanh hơn những người cao tuổi. Người bệnh không có thói quen hút thuốc và/hoặc uống rượu có kết quả chăm sóc tốt cao hơn, nhóm người bệnh không có bệnh lý kèm theo có kết quả chăm sóc tốt cao hớn nhóm có bệnh lý.

Phương pháp mổ nội soi và thời điểm ăn đường miệng nhỏ hơn hoặc bằng 3 ngày là hai yếu tố cho thấy kết quả chăm sóc tốt cao hơn. Đối với những yếu tố liên quan đến sự chăm sóc của điều dưỡng như tuân thủ việc rửa tay, tư vấn tâm lý, kiến thức, dinh dương hay hướng dẫn người bệnh vệ sinh thân thể, tuân thủ nội quy thì trong nghiền cứu này của chúng tôi chưa phát hiện có sự liên quan đến kết quả chăm sóc tốt của người bệnh sau phẫu thuật ung thư dạ dày.

\section{KẾT LUÂ̂N}

- Kết quả chăm sóc người bệnh tốt là 83,4\%.

- Các yếu tố liên quan đến kết quả chăm sóc tốt gồm: Nhóm tuổi, thói quan cá nhân, bệnh lý kèm theo, giai đoạn bệnh, phương pháp phẫu thuật và thời điểm ằn đường miệng.

\section{TÀI LIÊU THAM KHẢO}

1. IARC (2020), World cancer report: Cancer reseach for cancer prevetion. International Agency for Reseach on Cancer., Lyon, France.

2. Stomach Cancer Incidence and Mortality by Age group, New York State Excl New York City, 2014-2018.<https://www.health.ny.gov/statistics/ cancer/registry/table6/tb6stomachupstate.htm >,ac cessed: 24/10/2021. 
3. Li J., Zhang Y., Hu D.-M. và cộng sự. (2020). Impact of postoperative complications on longterm outcomes of patients following surgery for gastric cancer: A systematic review and metaanalysis of 64 follow-up studies. Asian J Surg, 43(7), 719-729.

4. Serra M.A.A. de O., Filho F.F. da S.,
Albuquerque A. de O. và cộng sự. (2015) Nursing care in the immediate postoperative period: a cross-sectional study. Online Braz J Nurs, 14(2), 161-7.

5. Qi S. và Yuanyuan W. (2019). Effect of systemic nursing on postoperative recovery of gastric cancer patients. Int J Curr Res, 11(11), 8179-8181.

\section{KIẾN THỨC CỦA NGƯờI NHIỄM HIV/AIDS VÊ TRÂM CẢM TẠI 2 PHÒNG KHÁM NGOẠI TRÚ TỈNH THÁI BÌNH}

\section{TÓM TẮT}

Mục tiêu: Đánh giá kiến thức của người nhiễm HIV/AIDS về trâm cảm tại 2 phòng khám ngoại trú tỉnh Thái Bình năm 2019. Đối tượng nghiên cứu: bệnh nhân HIV/AIDS người lớn $\geq 18$ tuổi đang điều trị ARV. Phương pháp nghiên cứu: Phương pháp mô tả thông qua cuộc điều tra cắt ngang. Kết quả nghiên cứu: Tỷ lệ đối tượng nghiên cứu đã từng được nghe ít nhất 1 lần về bệnh trầm cảm chiếm tỷ lể khá cao $(92,8 \%) ; 36,5 \%$ số đối tượng nghiên cứu biết được từ 4/6 biểu hiện của cả 2 giai đoạn khởi phát và toàn phát của bệnh; Chỉ có $31,6 \%$ người bệnh kể được 2-3 trong số 3 nhóm nguyên nhân chính; Tỷ lệ đối tượng nghiên cứu có kiến thức đạt về trầm cảm chiếm tỷ lệ 69,7\% Bình.

Tư khóa: Kiến thức về trâm cảm; HIV/AIDS; Thái

\section{SUMMARY \\ KNOWLEDGE OF HIV/AIDS PATIENTS \\ ABOUT DEPRESSION AT 2 OUTPATIENT \\ CLINICS IN THAI BINH PROVINCE}

Objectives: Describe the knowledge of HIV/AIDS patients about depression at 2 outpatient clinics in Thai Binh province in 2019. Subjects: HIV / AIDS patients adults $\geq 18$ years old being treated with ARV. Method: Descriptive method through cross-sectional survey. Results: The percentage of study subjects who have heard at least 1 time about depression is quite high (92.8\%); And a low rate $(36.5 \%)$ of the study population knew from 4 out of 6 signs of the stages of the disease; Only $31.6 \%$ of patients known 2-3 of the 3 main causes of the depression; The percentage of study subjects with knowledge about depression was $69.7 \%$.

Keywords: Knowledge about depression; HIV/AIDS; Thai Binh

\footnotetext{
${ }^{1}$ Trường Đại học Y Dược Thái Bình

${ }^{2}$ Bênh viênn Bach Mai

Chịu trách nhiệm chính: Ngô Văn Mạnh

Email: manhsdh@gmail.com

Ngày nhận bài: 9.9.2021

Ngày phản biên khoa hoc: 29.10.2021

Ngày duyệt bài: 11.11.2021
}

Ngô Văn Mạnh ${ }^{1}$, Lê Đức Cường ${ }^{1}$, Bùi Thị Huyền Diệu ${ }^{1}$, Vũ Thị Quỳnh Trang ${ }^{2}$

\section{I. Đă̆T VẤN ĐỀ}

Hơn 30 năm qua, kể từ khi phát hiện ra HIV cho đên nay, cộng đồng quốc tế đã nỗ lực rất lớn trong công tác chăm sóc, điều trị HIV/AIDS nhằm đẩy lùi sự gia tăng của đại dịch AIDS và đã thu đước nhiêu kết quả đáng ghi nhân đó là sư phát triển tổng thể của dich AIDS toàn cầu có vẻ như đã ổn định. Số người nhiễm mới HIV hàng năm giảm xuống đáng kể từ cuối những năm 1990 và tử vong liên quan AIDS ít dân do việc mở rộng điều trị kháng HIV[1].

Cùng với nỗ lực điều trị HIV, ngoài việc người bệnh được hỗ trợ nhằm tăng cường sức khỏe thể chất thì sức khỏe tâm thần của người nhiễm HIV cũng là một trong những vấn đề cần được quan tâm. Người bệnh có thể gặp phải các vấn đề sức khỏe tầm thần bắt đầu từ rất sớm ngay khi có chẩn đoán ban đầu và có thể phát sinh trong cả thời gian điều trị bệnh. Các vấn đề phổ biến thường gặp phải là trầm cảm, lo âu và làm dụng các chất gây nghiện. Trong đó, trầm cảm là biên chứng thần kinh phổ biến nhất ở bênh nhân nhiếm HIV và hạn chế đáng kể chất lượng cuộc sống của bệnh nhîan HIV/AIDS [2].

Các nghiên cứu trên thế giới cũng cho thấy việc điều trị những người bệnh trầm cảm cũng thực sự khó khăn nếu như họ không tự nhận thức được vấn đề họ gặp phải. Các nhà nghiền cứu đã chỉ ra rằng nhận thức thấp về bệnh không những liên quan đến việc bệnh nhân trầm cảm không đên cơ sở chăm sóc y tế cho đến khi bệnh kéo dài, trở nên trầm trọng hơn mà còn ảnh hưởng lớn đối với việc tìm kiếm sư giúp đõ và cam kết với những can thiệp được đề nghị và cả phòng ngừa [3], [4]. Vì vậy chúng tôi tiến hành nghiên cứu để tài với mục tiêu:

Tìm hiểu kiến thức của người nhiễm HIV/AIDS về träm cảm tại 2 phòng khám ngoại trú tỉnh Thái Binh năm 2020. 